\title{
The incidence and distribution of anomalies found in the pregnant women applied to Kayseri City Hospital for obstetric ultrasound in 2019: a retrospective analysis
}

\author{
Şadan Tutuş \\ Radiology Department, Kayseri City Hospital, Kayseri, Turkey
}

\begin{abstract}
Objective: Our aim is to determine the incidence and distribution of anomalies found in the pregnant women referred to the first obstetric radiology outpatient clinic of our hospital for ultrasound (US) examination in 2019.

Methods: A total of 5661 obstetric US examinations were performed in 4018 pregnant women, 588 of whom were foreigners, for routine control, follow-up and screening purposes between January 1 and December 31, 2019, and their results were analyzed retrospectively after obtaining the approval of ethics committee. All US examinations were conducted by a single radiologist (ŞT) with Canon Aplio 500 ultrasound device (Canon Medical Systems Corporation, Tokyo, Japan) using 3.5 Mhz convex probe. The results of the cases with anomalies were accessed and grouped systematically, and their incidence and distribution were reviewed by comparing with the literature.

Results: As a result of the reviewed obstetric US examinations, a total of 62 fetuses with anomalies, 17 of whom were from the foreign pregnant women, were found to have anomalies. Of these anomalies, 29 were craniospinal, 10 were genitourinary, 6 were cardiac, 6 were skeletal, 3 were gastrointestinal, 2 were thoracic and 6 were unclassified. The pregnant women were between 17 and $43(27.5 \pm 7.21)$ years old and their weeks of gestation were varying between 11 and $39(22.3 \pm 8.63)$ weeks. There were $8(13 \%)$ pregnant women younger than 20 years old, 43 (69\%) pregnant women between 20 and 35 years old, and $11(18 \%)$ pregnant women older than 35 years old. Anomaly diagnosis was established during first trimester in $14(22.5 \%)$ fetuses, 26 (42\%) fetuses during second trimester, and 22 (35.5\%) fetuses during third trimester.

Conclusion: We found in our study that the incidence of fetuses with congenital anomaly was $1.54 \%$ in total, $2.89 \%$ in foreigners and $1.31 \%$ in Turkish citizens. The most common anomaly is acrania with $7(0.15 \%)$ cases, and the diagnosis was established during first trimester in six of them. Detailed fetal screening during first trimester is very important for the detection of non-chromosomal anomalies. However, second- and third-trimester examinations are also important for the accurate diagnosis in pregnancies without follow-up.
\end{abstract}

Keywords: Fetal congenital anomaly, ultrasound, prenatal diagnosis, anomaly screening.
Özet: Kayseri Şehir Hastanesine 2019 yılında obstetrik ultrasonografi için başvuran gebelerde saptanan anomali sıklığı ve dağılımı: Retrospektif analiz

Amaç: Hastanemiz birinci obstetrik radyoloji polikliniğine 2019 yılında ultrasonografi (US) bakısı için gönderilen gebelerde saptanan anomalilerin görülme sıklığı ve dağılımını belirlemektir.

Yöntem: 1 Ocak - 31 Aralık 2019 tarihleri arasında 588'i yabancı uyruklu olmak üzere toplam 4018 gebeye rutin kontrol, takip ve tarama amaçlı 5661 obstetrik US tetkiki yapıldı ve sonuçları etik kurul onayı alındıktan sonra retrospektif olarak analiz edildi. Tüm ultrasonografik muayeneler tek radyolog (ŞT) tarafindan Canon Aplio 500 ultrason cihazında (Canon Medical Systems Corporation, Tokyo, Japonya), 3.5 Mhz konveks prob kullanılarak gerçekleştirildi. Anomali tespit edilen olguların sonuçlarına ulaşılıp sistematik gruplandırma yapılarak literatür eşliğinde görülme sıklı̆̆ı ve dağılımı araştırıldı.

Bulgular: İncelenen obstetrik US tetkikleri sonucunda 17'si yabancı uyruklu gebelere ait olmak üzere toplam 62 anomalili fetüs tespit edildi. Bu anomalilerin 29'u kraniyospinal, 10'u genitoüriner, altısı kalp, altısı iskelet sistemi, üçü gastrointestinal sistem, ikisi torakal ve altisı sinıflandirılamayan anomalilere aitti. Gebeler $17-43$ yaşları arasında $(27.5 \pm 7.21)$ ve gebelik haftaları $11-39$ hafta $(22.3 \pm 8.63)$ arasında değişmekteydi. 20 yaşından küçük sekiz (\%13), 20-35 yaş arası 43 (\%69) ve 35 yaşından büyük 11 (\%18) gebe mevcuttu. İlk trimesterde 14 (\%22.5), ikinci trimesterde 26 (\%42) ve üçüncü trimesterde 22 (\%35.5) fetüse anomali tanısı konuldu.

Sonuç: Çalışmamızda konjenital anomalili fetüs oranının toplamda \% 1.54 , yabancı uyruklularda \%2.89 ve TC vatandaslarında ise \% 1.31 olduğu görülmüştür. En sık görülen anomali 7 (\%0.15) olgu ile akranidir ve altısına ilk trimesterde tanı konulmuştur. İlk trimesterdeki ayrıntılı fetal taramanın kromozomal olmayan anomalilerin tespitinde önemi büyüktür. Ancak takipsiz gebeliklerin değerlendirilmesinde ikinci ve üçüncü trimester bakıları da doğru tanıda önem kazanmaktadır.

Anahtar sözcükler: Fetal konjenital anomali, ultrasonografi, prenatal tanı, anomali taraması.

Correspondence: Şadan Tutuş, MD. Radiology Department, Kayseri City Hospital, Kayseri, Turkey.

e-mail: sadantutus35@yahoo.com.tr / Received: November 11, 2020; Accepted: February 2, 2021

How to cite this article: Tutuş Ş. The incidence and distribution of anomalies found in the pregnant women applied to Kayseri City Hospital for obstetric ultrasound in 2019: a retrospective analysis. Perinatal Journal 2021;29(1):54-62. doi:10.2399/prn.21.0291009 


\section{Introduction}

The role of ultrasound (US) in the daily practice is very important to make decisions in the management of pregnancy and labor. The use of US in pregnancy is for screening and diagnosis purposes. Screening and diagnosis are two related but different practices. The purpose in screening is to determine the risk in terms of chromosomal anomalies. Diagnostic US is done for the detection of major structural anomalies. ${ }^{[1]}$ In many countries, second-trimester screening is done routinely in pregnancies with low and high risks in order to evaluate fetal anatomy. Fetal examination is also performed meticulously regardless of the week of gestation.

In this study, obstetric US results were reviewed which were performed by a single radiologist in the first obstetric radiology outpatient clinic of our hospital in 2019.

\section{Methods}

A total of 5661 obstetric US examinations were performed in 4018 pregnant women, 588 of whom were foreigners, for routine control, follow-up and screening purposes who applied to the first obstetric radiology outpatient clinic between January 1 and December 31, 2019. After obtaining the approval of ethics committee, the results were analyzed retrospectively. All US examinations were done by a single radiologist (STT), who was experienced in obstetric and gynecologic US, with Canon Aplio 500 US device (Canon Medical Systems Corporation, Tokyo, Japan) using 3.5 Mhz convex probe. The US examination was performed in accordance with the recommendations provided in the current guidelines of The International Society of Ultrasound in Obstetrics and Gynecology (ISUOG). The week of gestation was determined according to the last menstrual period in the pregnant women with regular menstrual cycle. In other pregnant women, the week of gestation was determined according to the crownrump length measurement in the first trimester, if any, or otherwise biparietal diameter (BPD) and/or head circumference (HC) or femur length (FL) measurement in the second trimester. Fetal BPD, HC, abdomen circumference (AC) and FL were measured for fetal biometry. Estimated fetal weight was calculated. Fetuses were examined systematically, and fetal movements and fetal wellbeing were observed. In addition, placenta, cervix and umbilical cord were evaluated in terms of other pathologies that may be overlooked. The amount of amniotic fluid was calculated by four-quadrant examination. In the evaluation of fetuses at the last trimester, both uterine arteries were assessed by umbilical artery and mid-cerebral artery Doppler examination, and fetal growth was interpreted. The fetuses found to have anomaly were classified according to the system that anomaly was associated, and the results of the cases were followed up. The incidence and distribution of anomalies were investigated by grouping systematically via frequency analysis method and comparing with the literature.

\section{Results}

As a result of evaluated obstetric US examinations, a total of 62 fetuses with anomalies were found, 17 of whom were from foreign pregnant women. Of these anomalies, 29 were craniospinal, 10 were genitourinary, 6 were cardiac, 6 were skeletal, four were gastrointestinal system, 2 were thoracic and 6 were unclassified (Table 1). The pregnant women were between 17 and $43(27.5 \pm 7.21)$ years old and their weeks of gestation were varying between 11 and $39(22.3 \pm 8.63)$ weeks. There were 8 (13\%) pregnant women younger than 20 years old, 43 (69\%) pregnant women between 20 and 35 years old, and 11 (18\%) pregnant women older than 35 years old. Anomaly diagnosis was established during first trimester in $14(22.5 \%)$ fetuses, 26 (42\%) fetuses during second trimester, and $22(35.5 \%)$ fetuses during third trimester (Table 2). No cardiac, genitourinary and thoracic anomalies were found in the first trimester. Twenty-one of the fetuses with anomaly were aborted due to anomalies that are not compatible with life upon the recommendation of perinatologist and the decision of the family. For five fetuses, the families requested to wait for labor, but they were delivered upon intrauterine death in the gestational follow-up. Six fetuses were delivered in the advanced weeks of gestation, but they died depending on the anomaly severity within the first three months. One fetus with the diagnosis of polycystic kidney and occipital encephalocele (Meckel-Gruber syndrome; Figs. 1a and 1b) developed premature rupture of membrane after 20 weeks of gestation and ended with abortion. The remaining 29 fetuses were born and their follow-ups and treatments were initiated according to their diagnoses. The most common anomaly was acrania detected in 7 (0.15\%) cases, three of whom also had craniorachischisis (Fig. 2). Thirteen of 21 aborted fetuses had craniospinal anom- 
Table 1. Distribution and numbers of anomalies detected by the systems.

\begin{tabular}{|c|c|c|}
\hline System & Anomaly & Number \\
\hline \multirow{12}{*}{$\begin{array}{l}\text { Craniospinal } \\
\text { anomalies } \\
(46.7 \%)\end{array}$} & Acrania & 7 (3 cases together with craniorachischisis) \\
\hline & Iniencephaly & $\begin{array}{l}3 \text { (one case together with Blake's pouch cyst and clubfoot, } \\
\text { one case together with clubfoot) }\end{array}$ \\
\hline & Chiari 2 & 4 (one case together with meningocele) \\
\hline & Chiari 3 & 1 (occipital encephalocele) \\
\hline & Frontal cephalocele & 1 \\
\hline & Meningocele + diastematomyelia + NTD in T-L region & 1 \\
\hline & CC agenesis & $\begin{array}{l}5 \text { (one case together with Blake's pouch cyst, one case together } \\
\text { with Blake's pouch cyst and bilateral renal agenesis, one case } \\
\text { together with Dandy-Walker malformation) }\end{array}$ \\
\hline & Vein of Galen aneurysm & 2 \\
\hline & Lobar holoprosencephaly & 1 (together with proboscis and polycystic kidney) \\
\hline & Alobar holoprosencephaly & 1 \\
\hline & Arachnoid cyst & 1 \\
\hline & Vertebral alignment disorder & 2 \\
\hline \multirow{7}{*}{$\begin{array}{l}\text { Genitourinary system } \\
\text { anomalies }(16.1 \%)\end{array}$} & MCDB & 2 \\
\hline & Meckel-Gruber syndrome & 1 (polycystic kidney, occipital encephalocele) \\
\hline & Right kidney agenesis & 1 \\
\hline & Ovarian cyst & 2 (one is complicated) \\
\hline & Hydroureter, hydronephrosis & 1 \\
\hline & Hydronephrosis & 2 \\
\hline & Polycystic kidney & 1 \\
\hline \multirow{6}{*}{$\begin{array}{l}\text { Heart anomalies } \\
(9.6 \%)\end{array}$} & Endocardial fibroelastosis & 1 \\
\hline & AVSD + pulmonary stenosis & 1 \\
\hline & Tricuspid atresia + right ventricular hypoplasia & 1 \\
\hline & Hypoplastic left heart + DV agenesis & 1 \\
\hline & Hypertrophic cardiomyopathy & 1 \\
\hline & AVSD + single atrium + ARSA + hydronephrosis & 1 \\
\hline \multirow{5}{*}{$\begin{array}{l}\text { Skeletal system } \\
\text { anomalies }(9.6 \%)\end{array}$} & Thanatophoric dysplasia & 2 \\
\hline & Achondroplasia & 1 \\
\hline & Skeletal dysplasia (micromelia) & 1 \\
\hline & Polydactyly in both hands and feet & 1 \\
\hline & Right hand finger agenesis & 1 \\
\hline \multirow{3}{*}{$\begin{array}{l}\text { Gastrointestinal system } \\
\text { anomalies } \\
(4.8 \%)\end{array}$} & Anal atresia & 1 \\
\hline & Omphalocele & 1 \\
\hline & Gastroschisis & 1 \\
\hline \multirow{3}{*}{$\begin{array}{l}\text { Unclassified } \\
\text { anomalies } \\
(9.6 \%)\end{array}$} & Cystic hygroma & 4 \\
\hline & Acardiac twin & 1 \\
\hline & Fetal hydrops, cardiomegaly & 1 \\
\hline \multirow{2}{*}{$\begin{array}{l}\text { Thoracic anomaly } \\
(3.2 \%)\end{array}$} & Congenital upper airway obstruction & 1 \\
\hline & Congenital diaphragmatic hernia & 1 \\
\hline
\end{tabular}

ARSA: aberrant right subclavian artery; AVSD: atrioventricular septal defect; CC: corpus callosum; DV: ductus venosus; MCDB: multicystic dysplastic kidney; NTD: neural tube defect; T-L: thoracolumbar.

alies, three had unclassified anomalies, two had thoracic anomalies (Fig. 3), one had gastrointestinal system anomaly, one had skeletal system anomaly and one had cardiac anomaly. Of the fetuses who died intrauterinely during pregnancy period, three had craniospinal anomaly, one had cardiac anomaly, and one had unclassified anomalies. Of the fetuses who died during postnatal follow-up, three had craniospinal anomaly, two had cardiac anomaly, and one had skeletal system anomaly. Of 29 fetuses followed up after birth, ten had craniospinal anomaly (Fig.
4), nine had genitourinary system anomaly, four had skeletal system anomaly, two had cardiac anomaly (Fig. 5), two had gastrointestinal system anomaly (Fig. 6), and two had unclassified anomalies (Table 3).

\section{Discussion}

While the diagnoses of fetal anomalies vary according to the trimesters, the anomalies can be detected accurately in the earlier weeks of gestation thanks to the technolog- 
The incidence and distribution of anomalies found in the pregnant women applied to Kayseri City Hospital for obstetric US

Table 2. Distribution and numbers of anomalies by the trimesters.

\begin{tabular}{|c|c|c|}
\hline Trimester & Anomaly & Number \\
\hline \multirow{8}{*}{$\begin{array}{l}\text { First trimester: } \\
14 \text { Anomalies }(22.5 \%)\end{array}$} & Acrania & 6 \\
\hline & Cystic hygroma & 2 \\
\hline & Meningocele + diastematomyelia + (NTD) in T-L region & 1 \\
\hline & Iniencephaly & 1 \\
\hline & Acardiac twin & 1 \\
\hline & Gastroschisis & 1 \\
\hline & Omphalocele & 1 \\
\hline & Thanatophoric dysplasia & 1 \\
\hline \multirow{20}{*}{$\begin{array}{l}\text { Second trimester: } \\
26 \text { Anomalies (42\%) }\end{array}$} & CC agenesis & 3 \\
\hline & MCDB & 1 \\
\hline & Cystic hygroma & 2 \\
\hline & Frontal cephalocele & 1 \\
\hline & Endocardial fibroelastosis & 1 \\
\hline & Right kidney agenesis & 1 \\
\hline & Chiari 3 & 1 \\
\hline & Chiari 2 & 3 \\
\hline & Diaphragmatic hernia & 1 \\
\hline & Hypoplastic left heart & 1 \\
\hline & Right ventricular hypoplasia, tricuspid atresia & 1 \\
\hline & Thanatophoric dysplasia & 1 \\
\hline & Vertebral alignment disorder & 1 \\
\hline & AVSD, pulmonary stenosis & 1 \\
\hline & Meckel-Gruber syndrome & 1 \\
\hline & Acrania & 1 \\
\hline & Upper airway obstruction & 1 \\
\hline & Anencephaly & 2 \\
\hline & Polydactyly in both hands and feet & 1 \\
\hline & Right hand finger agenesis & 1 \\
\hline \multirow{18}{*}{$\begin{array}{l}\text { Third trimester: } \\
22 \text { Anomalies (35.5\%) }\end{array}$} & Ovarian cyst & 2 \\
\hline & CC agenesis & 2 \\
\hline & Vein of Galen aneurysm & 2 \\
\hline & Hydronephrosis & 2 \\
\hline & Arachnoid cyst & 1 \\
\hline & Alobar holoprosencephaly & 1 \\
\hline & Late-onset achondroplasia & 1 \\
\hline & Anal atresia & 1 \\
\hline & Chiari 2 & 1 \\
\hline & Fetal hydrops & 1 \\
\hline & Skeletal dysplasia (micromelia) & 1 \\
\hline & Lobar holoprosencephaly & 1 \\
\hline & Vertebral alignment disorder & 1 \\
\hline & Hydroureter, hydronephrosis & 1 \\
\hline & Hypertrophic cardiomyopathy & 1 \\
\hline & Polycystic kidney & 1 \\
\hline & MCDB & 1 \\
\hline & AVSD + single atrium + ARSA + hydronephrosis & 1 \\
\hline
\end{tabular}

ARSA: aberrant right subclavian artery; AVSD: atrioventricular septal defect; CC: corpus callosum; DV: ductus venosus; MCDB: multicystic dysplastic kidney; NTD: neural tube defect; T-L: thoracolumbar.

ical developments in the US devices nowadays. Syngelaki et al. ${ }^{[2]}$ classified fetal anomalies in three groups according to the first trimester which are always detectable, potentially detectable and undetectable anomalies. According to this classification, body-stalk anomaly, anencephaly-acrania, alobar holoprosen- cephaly, omphalocele, gastroschisis and megacystis anomalies are always detectable. Microcephaly and corpus callosum agenesis are the anomalies that cannot be detected in the first trimester but can be diagnosed in the second trimester. Echogenic lung masses, duodenal and intestinal atresias, fetal tumors and obstructive patholo- 

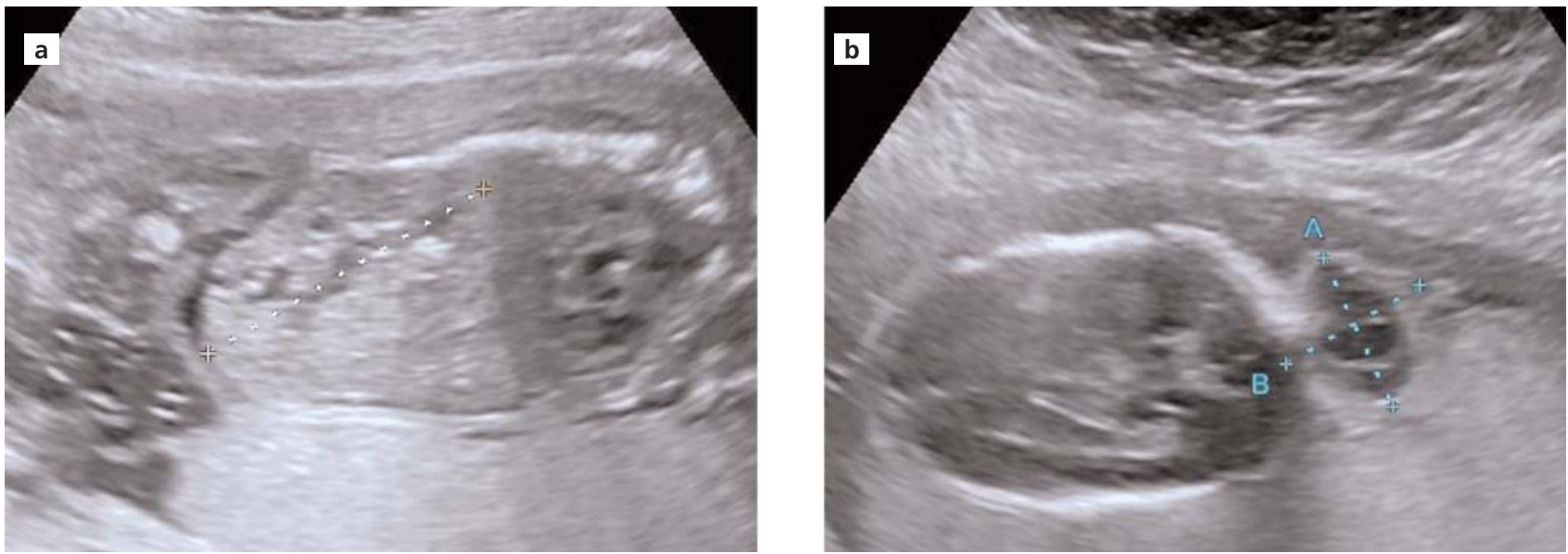

Fig. 1. (a) 20 weeks of gestation; large hyperechogenic kidney and anhydramnios are present. (b) Occipital encephalocele view of the same fetus; Meckel-Gruber syndrome.

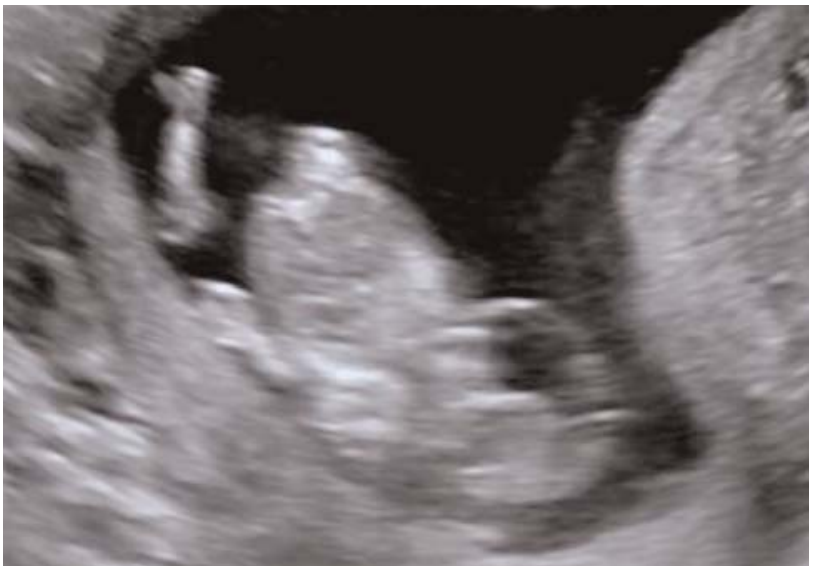

Fig. 2. Acrania case in a pregnancy at 12 weeks of gestation.

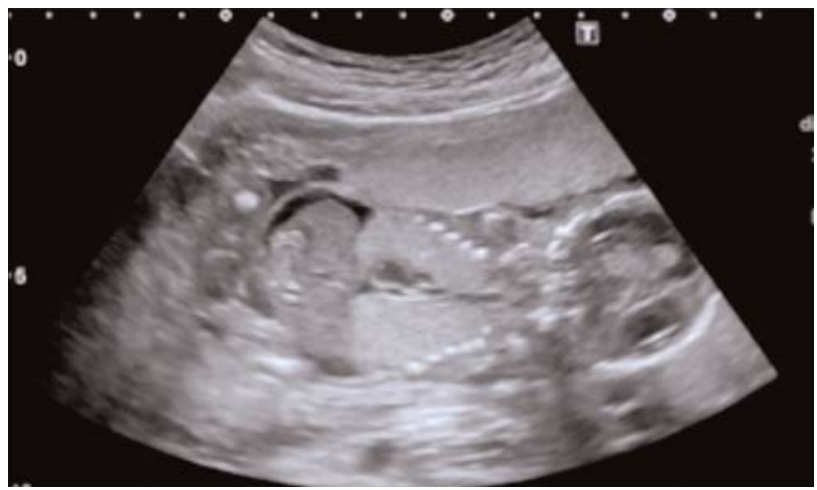

Fig. 3. 17 weeks of gestation; wide hyperechogenic lungs, diaphragm is reversed, and the heart is compressed in the middle, upper airway obstruction, laryngeal atresia case. gies that may cause hydronephrosis can be diagnosed in the second and third trimesters while ovarian cysts can be detected usually in the third trimester. ${ }^{[2]}$ Posterior fossa anomalies, cleft palate and lip, spina bifida, cardiac and renal anomalies and diaphragmatic hernia can be overlooked in the first trimester. Extremity reduction anomalies can be detected usually in the first trimester. In our study, there were one case with omphalocele anomaly and one case with gastroschisis (Fig. 6) which were detected in the first trimester, one fetus with acrania was diagnosed in the second trimester, and one fetus with alobar holoprosencephaly was detected in the third trimester. Also, three of five fetuses with corpus callosum agenesis were diagnosed in the third trimester (Fig. 4),

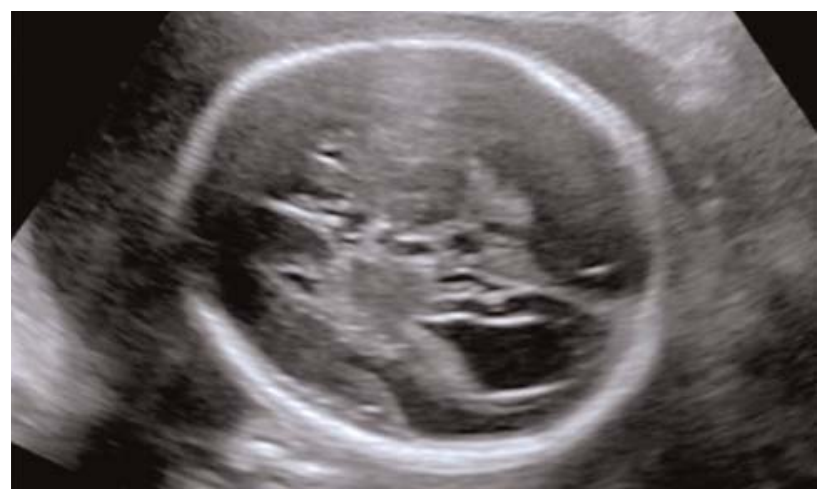

Fig. 4. 26 weeks of gestation; ventriculomegaly and colpocephaly view, corpus callosum agenesis. 
and one case with finger agenesis was diagnosed in the second trimester. The rate of diagnosing anomalies in the first trimester was $22.5 \%$ in our study compared to all anomalies. This rate being lower than second and third trimesters is associated with the fact that pregnancies were not followed up and necessary routine screenings were not carried out on time. Detailed fetal screening in the first trimester is very important for the detection of non-chromosomal anomalies.

Fetal central nervous system (CNS) anomalies is seen with a rate of $0.1-0.2 \%$ in live births, and $3-6 \%$ in stillbirths, and they are severe pathologies presenting with high morbidity. ${ }^{[3]}$ In their study, Tutus et al. ${ }^{[4]}$ found that the rate of CNS anomaly during intrauterine period was $0.28 \%$. CNS anomalies are the second most common congenital anomalies after cardiac anomalies. Therefore, examining neurological system is a very critical part of routine fetal anomaly screening. It was reported that $\mathrm{CNS}$ anomalies are responsible for $75 \%$ of fetal deaths, and $40 \%$ of childhood deaths. ${ }^{[5]}$ In our study, we included CNS and spinal anomalies in the same group, and they constituted $46 \%$ of current detected anomalies and $0.72 \%$ of all pregnancies. There are three isolated spinal anomalies, and when they are excluded, CNS anomaly rate drops to $0.64 \%$. The most common anomaly in total is acrania with seven $(0.15 \%)$ cases, and six of them received diagnosis in the first trimester. Onkar et al. ${ }^{[6]}$ reported in their study that anencephaly was the most common fetal CNS anomaly.

Congenital urinary system anomalies include morphological and functional malformations in the various levels of kidney, ureter, bladder and urethra. The rate of these anomalies vary between 0.3 and 1.6 per 1000 labors. ${ }^{[7]}$ They constitute $15-20 \%$ of all anomalies in the prenatal period. ${ }^{[8]}$ The rate of urinary system malformations detected prenatally increases as the week of gestation advances. In our study, we found three anomalies in the second trimester and seven anomalies in the third trimester together with ovarian cysts (Table 2).

Congenital heart anomalies are seen in 8 of 1000 live births and they are the most common anomaly group. About half of these cases are severe anomalies and most of them require surgical procedure. ${ }^{\left[{ }^{[9]}\right.}$ Some malformations cannot be detected before birth due to the physiological characteristics of fetal circulation between heart and major arteries; therefore, the diagnosis can be established just after the birth. The rate of detecting cardiac anomalies during prenatal screening varies between $5 \%$

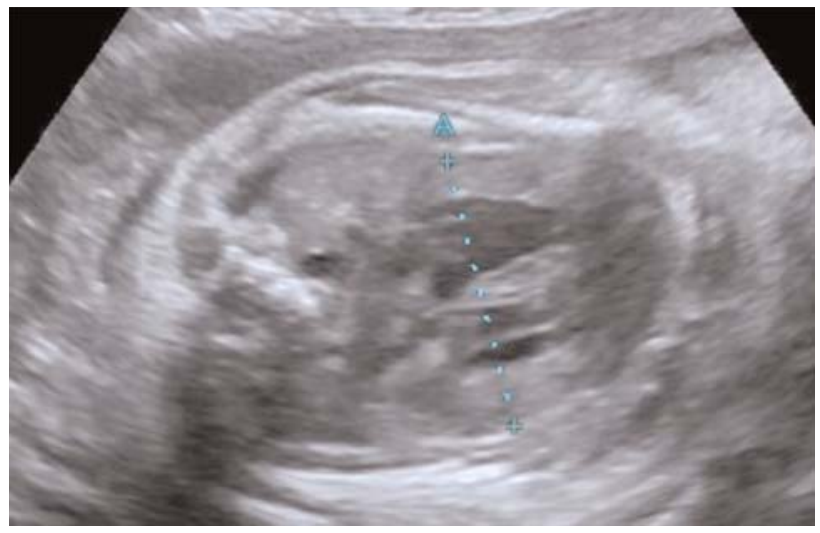

Fig. 5. 28 weeks of gestation; cardiomyopathy is seen.

and $85 \% .^{[10]}$ In our study, we detected cardiac anomaly only in six of 62 fetuses with anomalies, which is equal to $9.6 \%$ of all detected anomalies. The rate is $0.14 \%$ among all pregnant women who underwent US. We detected no cardiac anomaly in the first trimester while we established the diagnosis of cardiac anomaly in four cases in the second trimester and in two cases in the third trimester. We managed to diagnose one case with hypertrophic cardiomyopathy in the third trimester when the appearance became apparent in the second sonographic examination (Fig. 5). We associated the low rate of cardiac anomaly in our study with the fact that each pregnant woman who underwent US could not be checked within the appropriate week for cardiac anomaly detection and that some anomalies became detectable after the birth.

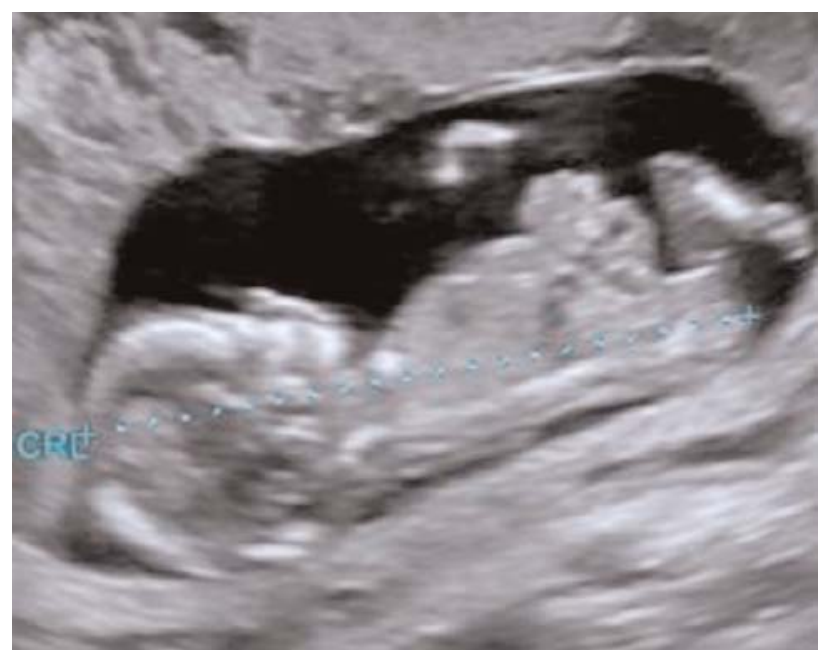

Fig. 6. 13 weeks of gestation; gastroschisis anomaly is seen. 
Table 3. Clinical follow-up of the detected anomalies.

\begin{tabular}{|c|c|c|}
\hline Cases & Systems & Number and diagnosis \\
\hline \multirow{11}{*}{$\begin{array}{l}\text { Aborted cases } \\
\text { ( } 21 \text { fetuses) }\end{array}$} & 1- Craniospinal anomaly (13 fetuses) & 7 Acrania \\
\hline & & 3 Chiari 2 \\
\hline & & 1 Chiari 3 \\
\hline & & 1 Iniencephaly \\
\hline & & $1 \mathrm{CC}$ agenesis (together with Blake's pouch cyst and bilateral renal agenesis) \\
\hline & 2- Unclassified anomalies (3 fetuses) & 3 Cystic hygroma \\
\hline & 3- Thoracic anomaly (2 fetuses) & 1 Congenital diaphragmatic hernia \\
\hline & 4- Gastrointestinal system (1 fetus) & 1 Congenital upper airway obstruction \\
\hline & 5- Skeletal system (1 fetus) & 1 Omphalocele \\
\hline & 6- Cardiac anomaly (1 fetus) & 1 Thanatophoric dysplasia \\
\hline & & 1 Tricuspid atresia + right ventricular hypoplasia \\
\hline \multirow{4}{*}{$\begin{array}{l}\text { Cases died intrauterinely } \\
\text { during gestational } \\
\text { follow-up ( } 5 \text { fetuses) }\end{array}$} & 1- Craniospinal anomaly (3 fetuses) & 1 Frontal cephalocele \\
\hline & & $\begin{array}{l}1 \text { Arachnoid cyst } \\
1 \text { Iniencephaly }\end{array}$ \\
\hline & 2- Cardiac anomaly (1 fetus) & 1 AVSD + pulmonary stenosis \\
\hline & 3- Unclassified anomaly (1 fetus) & 1 Cystic hygroma \\
\hline \multirow{4}{*}{$\begin{array}{l}\text { Cases died } \\
\text { after birth } \\
\text { ( } 6 \text { fetuses) }\end{array}$} & 1- Craniospinal anomaly (3 fetuses) & $\begin{array}{l}1 \text { Alobar holoprosencephaly + proboscis + polycystic kidney) } \\
1 \text { Vertebral alignment disorder }\end{array}$ \\
\hline & & 1 Iniencephaly + Blake's pouch cyst + clubfoot \\
\hline & 2- Cardiac anomaly (2 fetuses) & $\begin{array}{l}1 \text { Endocardial fibroelastosis } \\
1 \text { Hypoplastic left heart + DV agenesis }\end{array}$ \\
\hline & 3- Skeletal system (1 fetus) & 1 Thanatophoric dysplasia \\
\hline $\begin{array}{l}\text { Preterm labor due to } \\
\text { PPROM ( } 1 \text { fetus) }\end{array}$ & 1- Genitourinary system (1 fetus) & 1 Meckel-Gruber syndrome \\
\hline \multirow[t]{21}{*}{$\begin{array}{l}\text { Cases followed up } \\
\text { after birth ( } 29 \text { fetuses) }\end{array}$} & 1- Craniospinal anomaly (10 fetuses) & $\begin{array}{l}2 \text { CC agenesis } \\
1 \text { CC agenesis + Blake's pouch cyst }\end{array}$ \\
\hline & & 1 CC agenesis + Dandy-Walker anomaly \\
\hline & & 1 Chiari 2 \\
\hline & & 1 Lobar holoprosencephaly \\
\hline & & 2 Vein of Galen aneurysm \\
\hline & & 1 Scoliosis \\
\hline & & 1 Meningocele + NTD + diastematomyelia in T-L region \\
\hline & 2- Genitourinary system anomaly (9 fetuses) & $2 \mathrm{MCDB}$ \\
\hline & & 2 Ovarian cyst \\
\hline & & 2 Hydronephrosis \\
\hline & & 1 Hydroureter + hydronephrosis \\
\hline & & 1 Right kidney agenesis \\
\hline & & 1 Polycystic kidney \\
\hline & 3- Skeletal system (4 fetuses) & 1 Micromelia \\
\hline & & 1 Late-onset achondroplasia \\
\hline & & 1 Right hand finger agenesis \\
\hline & & 1 Polydactyly \\
\hline & 4- Cardiac anomaly ( 2 fetuses) & $\begin{array}{l}1 \text { AVSD + single atrium + ARSA + hydronephrosis } \\
1 \text { Hypertrophic cardiomyopathy }\end{array}$ \\
\hline & 5- Gastrointestinal system (2 fetuses) & $\begin{array}{l}1 \text { Gastroschisis } \\
1 \text { Anal atresia }\end{array}$ \\
\hline & 6- Unclassified anomaly (2 fetuses) & 1 Acardiac twin \\
\hline & & 1 Fetal hydrops \\
\hline
\end{tabular}

ARSA: aberrant right subclavian artery; AVSD: atrioventricular septal defect; CC: corpus callosum; DV: ductus venosus; MCDB: multicystic dysplastic kidney; NTD: neural tube defect; PPROM: preterm premature rupture of membranes; T-L: thoracolumbar.

Skeletal system anomalies are seen in about $1 / 5000$ cases. ${ }^{[1]]}$ It is difficult to diagnose both in prenatal and postnatal periods. Furthermore, obstetric management may be insufficient as the most of the detectable skeletal dysplasias in fetuses are fatal. The point to remember here is that it is important to know in which week of ges- 
tation the skeletal system anomaly would appear depending on its type, to know its development and the bones it would affect. ${ }^{[12]}$ While extremity reduction anomalies can be detected in the first trimester, the developmental anomalies such as achondroplasia can be detected after second trimester when they become detectable. The rate of skeletal system anomaly was $0.14 \%$ in our study.

In the comprehensive Eurofetus study assessing routine obstetric US performance, the sensitivity of US was reported $54 \%$ for gastrointestinal system while it was $89 \%$ for urinary system. ${ }^{[13]}$ The points to consider in the routine assessment of gastrointestinal system are the presence, size and position of stomach, insertion of umbilical cord into abdomen and the number of vessels in cord. ${ }^{[14]}$ In our study, there were three cases with gastrointestinal system anomaly, the rate of which was $0.07 \%$ in the total study population.

Airways and lungs being full of fluid in the intrauterine period makes fetal thorax and lungs appropriate anatomical structures for both US and magnetic resonance imaging. ${ }^{[15]}$ US examination of thorax can be done easily up to 25-26 weeks of gestation. However, a significant number of thoracic anomalies appear in the further weeks of gestation. Therefore, it should be paid attention to thoracic anomalies when examining in the third trimester. In our study, there were two cases with thoracal anomaly, one of which was upper airway obstruction (Fig. 3) while the other one was diaphragmatic hernia, and we detected both of them in the second trimester. Total thoracic anomaly rate was $0.04 \%$ in the study population.

There were a total of six cases with unclassified anomalies. Four of them were diagnosed with cystic hygroma, and three of them were aborted while fourth one died intrauterinely. Other cases with fetal hydrops and acardiac twin ended with birth.

In our study, the rates of fetuses with congenital anomaly was $1.54 \%$ in total, while it was $2.89 \%$ in foreigners and $1.31 \%$ in Turkish citizens. The rate of congenital anomaly was between $0.29 \%$ and $2.79 \%$ in various studies conducted in Turkey, and our results are consistent with these values. ${ }^{[16,17]}$ Syngelaki et al. ${ }^{[18]}$ reviewed sonographic examinations of 100,997 pregnant women and found the incidence of fetal anomaly $1.7 \%$. When they evaluated by the trimesters, they detected anomalies with a rate of $27.6 \%$ in the first trimester, $53.8 \%$ in the second trimester, and $18.6 \%$ in the third trimester and postnatal period. The anomaly detection rate in the third trimester was $35.5 \%$ in our study. We associated this high rate with the fact that the pregnant women were not followed up and admitted to the hospital at a time close to delivery. Ficara et al. ${ }^{[19}$ found that the rate of anomalies detected first, including ovarian cyst, microcephaly, achondroplasia, dacryocystocele and hematocolpos, was $0.5 \%$ when they reviewed the sonographic examination between 35 and 37 weeks of gestation for 52.400 pregnant women who underwent screenings at 18-24 weeks of gestation including sonographic examinations at 11-13 weeks of gestation for the majority. The authors found that most detected anomalies at postnatal period were isolated cleft palate and lip, polydactyly and syndactyly, ambiguous genitalia and hypospadias with an incidence of $0.1 \%$.

\section{Conclusion}

Fetal screening is conducted with the same accurateness in all weeks now, and the time spared for screening, the quality of device used, and the expert of the specialist affect the detection level of anomalies. As the anomalies are diagnosed at an earlier week, safer termination options are offered in the presence of fatal or severe anomalies, and the early diagnosis also enables to treat some fetal diseases. US examination at 11-13 weeks of gestation is used widely for the assessment of gestational age, the diagnosis of multiple pregnancy and chorionicity, fetal aneuploidy screening and the determination of non-chromosomal anomalies, and even for the preeclampsia screening in the high risk pregnancies. However, second- and third-trimester examinations are also important for the accurate diagnosis when evaluating non-followed up pregnancies. The rate of diagnosing anomalies in the third trimester in our study being higher than those reported in the literature also highlights this matter.

Funding: This work did not receive any specific grant from funding agencies in the public, commercial, or not-for-profit sectors.

Compliance with Ethical Standards: The author stated that the standards regarding research and publication ethics, the Personal Data Protection Law and the copyright regulations applicable to intellectual and artistic works are complied with and there is no conflict of interest. 


\section{References}

1. Ergün E. Birinci trimester ultrasonografi incelenmesi. Türk Radyoloji Seminerleri 2017;5:185-201. [CrossRef]

2. Syngelaki A, Chelemen T, Dagklis T, Allan L, Nicolaides KH. Challenges in the diagnosis of fetal non-chromosomal abnormalities at 11-13 weeks. Prenat Diagn 2011;31:90-102. [PubMed] [CrossRef]

3. Milani HJF, Barreto EQS, Araujo Júnior E, Peixoto AB, Nardozza LMM, Moron AF. Ultrasonographic evaluation of the fetal central nervous system: review of guidelines. Radiol Bras 2019;52:176-81. [PubMed] [CrossRef]

4. Tutus S, Ozyurt S, Yilmaz E, Acmaz G, Akin MA. Evaluation and prevalence of major central nervous system malformations: a retrospective study. North Clin Istanbul 2014;8:7883. [PubMed] [CrossRef]

5. Adama van Scheltema PN, Nagel HT, Brouwer OF, Vandenbussche FP. Outcome of children with prenatally diagnosed central nervous system malformations. Ultrasound Obstet Gynecol 2003;21:41-7. [PubMed] [CrossRef]

6. Onkar D, Onkar P, Mitra K. Evaluation of fetal central nervous system anomalies by ultrasound and its anatomical co-relation. J Clin Diagn Res 2014;8:AC05-7. [PubMed] [CrossRef]

7. Policiano C, Djokovic, Carvalho R, Monteiro C, Melo MA, Graça LM. Ultrasound antenatal detection of urinary tract anomalies in the last decade: outcome and prognosis. J Matern Fetal Neonatal Med 2015;28:959-63. [PubMed] [CrossRef]

8. Rodriguez MM. Congenital anomalies of the kidney and the urinary tract (CAKUT). Fetal Pediatr Pathol 2014;33:293320. [PubMed] [CrossRef]

9. Dilek TUK, Çayan F, Doruk A, Dorukan H. The role of 3D ultrasonography in the analysis of fetal cardiac anatomy. Perinatal Journal 2014;22:33-7. [CrossRef]
10. Entezami M, Albig M, Gasiorek-Weins A, Becker R. Ultrasound diagnosis of fetal anomalies. Berlin: Thieme; 2004. p. 80 .

11. Durmaz Alimoğlu, Özgür Ö. Fetal iskelet sistemi anomalileri. Türk Radyoloji Seminerleri 2017;5:284-98. [CrossRef]

12. Şen C, Meizner I. İskelet sistemi displazileri. Perinatoloji Dergisi 2002;2:76-80.

13. Grandjean H, Larroque D, Levi S. The performance of routine ultrasonographic screening of pregnancies in the Eurofetus study. Am J Obstet Gynecol 1999;181:446-54. [PubMed] [CrossRef]

14. Practice Guideline. AIUM-ACR-ACOG-SMFM-SRU practice parameter for the performance of standard diagnostic obstetric ultrasound examinations. J Ultrasound Med 2018;37: E13-E24. [PubMed] [CrossRef]

15. Dilek TUK, Doruk A, Köse S, Çayan F, Dilek S. The correlation of ultrasound and magnetic resonance imaging in the thoracic anomalies: case series. Perinatal Journal 2009;2:90-6.

16. Tomatir AG, Demirhan H, Sorkun HC, Köksal A, Özerdem F, Çilengir N. Major congenital anomalies: a five-year retrospective regional study in Turkey. Genet Mol Res 2009;8:1927. [PubMed] [CrossRef]

17. Bayhan G, Yalınkaya A, Yalınkaya Ö, Gül T, Yayla M, Erden AC. Dicle Üniversitesi Tip Fakültesi'nde konjenital anomali görülme sıklığı. Perinatoloji Dergisi 2000;8:99-103.

18. Syngelaki A, Hammami A, Bower S, Zidere V, Akolekar R, Nicolaides KH. Diagnosis of fetal non-chromosomal abnormalities on routine ultrasound examination at 11-13 weeks' gestation. Ultrasound Obstet Gynecol 2019;54:468-76. [PubMed] [CrossRef]

19. Ficara A, Syngelaki A, Hammami A, Akolekar R, Nicolaides KH. Value of routine ultrasound examination at 35-37 weeks' gestation in diagnosis of fetal abnormalities. Ultrasound Obstet Gynecol 2020;55:75-80. [PubMed] [CrossRef]

This work is licensed under the Creative Commons Attribution-NonCommercial-NoDerivs 4.0 Unported (CC BY-NC-ND4.0) License. To view a copy of this license, visit http://creativecommons.org/licenses/by-nc-nd/4.0/ or send a letter to Creative Commons, PO Box 1866, Mountain View, CA 94042, USA.

Publisher's Note: The content of this publication does not necessarily reflect the views or policies of the publisher, nor does any mention of trade names, commercial products, or organizations imply endorsement by the publisher. Scientific and legal responsibilities of published manuscript belong to their author(s). The publisher remains neutral with regard to jurisdictional claims in published maps and institutional affiliations. 